\title{
Regularity of a Crisis: Media Framing of the 2015 Transboundary Haze Issue in Indonesia, Singapore, and Malaysia
}

\author{
MIRA ROCHYADI-REETZ \\ Technische Universität IImenau, Germany
}

OLIVIA DESKARINA BOEDIONO

German Academic Exchange Service Regional Office Jakarta, Indonesia

JENS WOLLING

Technische Universität Ilmenau, Germany

\begin{abstract}
The problem of the haze caused by huge forest fires persists as an annual transboundary problem for Indonesia and the rest of Southeast Asia. In 2015, the problem was worse than ever before, affecting many countries in the Association of Southeast Asian Nations (ASEAN) and causing respiratory ailments for more than half a million Indonesians. This study explores the media framing of the haze problem in Indonesia from June to December 2015. Using Entman's framing approach, it investigates how media outlets from Indonesia, Malaysia, and Singapore covered the crisis. Articles from six online media outlets published in these three countries were analysed. Using cluster analysis, this research identified three frames as follows: (1) crisis frame, (2) immediate action frame, and (3) regular problem frame. The first cluster/frame consists of articles giving high salience to all problems and causes of the forest fires provoking the haze. In contrast, the second frame mostly ignores causes and problems and focuses almost exclusively on the need for immediate action. The third frame, which represents more than $60 \%$ of the articles, covers the haze problem as a regular issue without emphasizing prominently either the different aspects of the problem itself or its causes and solutions. Further results show that the media in Singapore and Malaysia used the crisis frame more often than the media in Indonesia.
\end{abstract}

Keywords: Framing, haze problem, content analysis, Southeast Asia, comparative research.

\section{INTRODUCTION}

Since 1982, several provinces in Indonesia have experienced a haze problem caused by forest fires during almost every dry season. However, the problem is not an Indonesian one alone; neighbouring countries in the Southeast Asian (SEA) region are also victims of the Indonesian haze (Varkkey, 2016; Jones, 2004). The SEA haze problem is "believed to be commonly caused by smoke from grass, forest and peat fires" (Cotton, 1999, as cited in Varkkey, 2016, p. 6). Most forest fires are consequences of the slash-and-burn practices of the agriculture sector. The intentionally set fires run out of control and burn forest as well as plantation areas (Varkkey, 2016). Debate is still ongoing about who is responsible for these fires. However, three groups have been identified as responsible for the creation of forest fires in the area: traditional cultivators, small-scale investors, and large-scale investors (Jones, 2004).

The $\mathbf{2 0 1 5}$ forest fires were not the first ones provoking transnational haze problems. Other major forest fire disasters have occurred in the region, including one in 1997 and another in 2006 (Varkkey, 2016). In 2015, however, the impact was greater than ever. The fires created huge haze problems in an extensive region for almost half a year (June until midNovember). As reported by The Jakarta Post, the 2015 haze disaster affected at least five 
countries in the Association of Southeast Asian Nations (ASEAN): Indonesia, Singapore, Malaysia, the southern part of Thailand, and the Philippines. The forest fires also generated more carbon dioxide than the total annual emissions of Germany (ABC, 2015).

This drew media from SEA to cover the issue. However, the prioritisation and the treatment of the issue was criticized as inadequate, considering the seriousness of the environmental issue (Monbiot, 2015). A possible reason for this failure might be related to the fact that the forest fires are linked to commercial plantations (palm oil, pulp, and paper), which are known for using slash-and-burn practices to clear land. Palm oil is an important commodity in the region and an important source of income. Furthermore, some palm plantations in Indonesia are owned by Malaysian and Singaporean companies. Therefore, the Indonesian government may find it problematic to combat the problem due to its economic interests (Varkkey, 2016).

Taking into account the seriousness of the problem not only for the region but also for the world's climate and considering the involved economic interests, an investigation into how the media cover the problem is vital. This is particularly true because the frames that the media set can influence political action and governmental response to the issue. This research investigates the coverage of the haze problem in three ASEAN countries that are involved in the issue in different ways. The problem originates in Indonesia, but Singapore and Malaysia are most affected by the haze. Considering the level of press freedom and related journalistic practices, the economic interests, and the varying impact of the haze in the three countries, the aim of this study is to investigate the differences in media coverage on the SEA haze problem. Using the concept of news framing, this study applied a quantitative content analysis method to several media outlets from different countries. The goal of this study is to answer the following research questions:

- (RQ1) What frames appear in the media coverage about the 2015 SEA haze problem?

- (RQ2) Are there any differences in the framing of the SEA haze problem between the media from Indonesia, Singapore, and Malaysia?

\section{Framing Approach}

\section{LITERATURE REVIEW}

Mass media play an important role in modern societies, as they are places where the political and social actors meet virtually and discuss relevant issues. In a democratic society, media coverage provides an insight into the viewpoints of the relevant actors on an issue, and as a result, the evolving picture of reality can be interpreted as a social construct of the issue. To investigate the social construction of the SEA haze problem caused by forest fires in 2015 , this study applies the framing approach. The basic idea of framing is that an issue can be understood and considered from different perspectives, which reflect the shared culture of a society as it changes over time (Pan \& Kosicki, 1993; Carvalho \& Burgess, 2005).

A literature review of Matthes (2009) showed that the most widely accepted definition of media framing is that given by Entman, who defined media framing as "to select some aspects of a perceived reality and make them more salient in a communicating text, in such a way as to promote a particular problem definition, causal interpretation, moral evaluation and/or treatment recommendation" (Entman, 1993, p. 52). This study operationalises the concept of news framing based on the concept proposed by Entman (1993) because the approach allows for the investigation of the details of the conflict as they are focused by the media (Matthes, 2009). By using Entman's (1993) concept of framing, this 
study aims to identify the dimensions of transboundary haze in SEA in 2015 and dive deeply into how these dimensions are portrayed in the media and what factors might influence the frame.

\section{State of Research on Transboundary Haze in SEA}

Surprisingly, despite the extreme relevance of the issue, there are only a few studies that analyse the political implications and even less that scrutinise the media coverage of the haze crisis in SEA. Most studies of the forest fires and haze in SEA have been done in the field of international relations, focusing on the issues of regionalism and regional political practices as well as evaluating policy implementations. An example of such research is a study by Jones (2004), who focused on ASEAN initiatives to combat the haze problem. Meanwhile, a study by Varkkey (2016) provided insights as to why the governments of Indonesia, Malaysia, and Singapore have failed to address the problem of haze appropriately, despite the clear evidence that plantations (especially palm oil plantations) in Indonesia are the culprit.

The only two studies on media coverage of forest fires and the SEA haze problem are those from Massey (2000) and Lin (2018). The study done by Massey (2000) aimed to determine the thematic breadth of the reporting on the Southeast Asian smoke-cloud haze of 1997-98. It applied computer-aided content analysis to three English newspapers: one each from Indonesia (The Jakarta Post), Malaysia (New Strait Times) and Singapore (The Strait Times). The study found 136 prominent issue-related words in the coverage and grouped them into 30 different clusters. These clusters were named as follows: (1) accidents, (2) agribusiness, (3) agriculture, (4) agricultural practice, (5) assistance, (6) battling the fires, (7) bureaucratic response, (8) community, (9) ecology, (10) El Niño, (11) emissions, (12) environmentalists, (13) experts, (14) forest fires, (15) government, (16) haze awareness, (17) human health, (18) legal action, (19) measuring the haze, (20) NGOs, (21) open burning, (22) haze/fire prevention, (23) rain as haze relief, (24) spraying, (25) suspects, 26) tourism, (27) tracking the haze, (28) traditional farmer, (29) visibility and (30) wildlife (Massey, 2000, p. 8081). Besides identifying the thematic clusters, Massey (2000) also found that all "newspapers emphasize nonconfrontational frames and downplay those that potentially were political sensitive" (p. 72). Since Indonesia, Singapore, and Malaysia are founders and members of ASEAN, which promotes partnership and collaboration between member states, Massey (2000) argued that journalists might be influenced by this ideology while reporting on the haze issue.

A recent study conducted by Lin (2018) looked at the transboundary haze crisis in ASEAN in 2013. This study differed from that conducted by Massey (2000) in that it only investigated the issue framing in Singapore. The author used a mixed methods approach and conducted a textual and web analysis of traditional, new, and social media during the peak days of the haze crisis in 2013. The web analysis showed that the Singaporean public mainly expressed negative sentiments about the crisis on Twitter. Meanwhile, textual analysis found that the majority of traditional media-affiliated online news sources covered the crisis based on positive assessments from the government and authorities. Singaporean traditional media reported carefully, as international relations with Indonesia might be affected negatively if the Indonesian treatment of the issue was criticized (Lin, 2018, p. 8). However, the picture was different in new media sources, such as popular blogs, in Singapore, which were also analysed in the study. Singaporean bloggers clearly used negative sentiments and harsh words to express their opinion on the haze crisis. Unlike traditional media, they blamed the governments of Singapore and Indonesia for not taking effective action to fight the haze. 
Based on the aforementioned findings by Massey (2000) and Lin (2018), we could deduce that traditional media coverage of the transboundary haze in ASEAN member countries tended to avoid confrontational or conflict frames and that this pattern remained the same over the past two decades.

\section{Structural Conditions as Influencing Factors on Framing of Haze}

From the perspective of media sociology, the production of media content by journalists is influenced by micro-, meso-, and macro-level factors (Shoemaker \& Reese, 2014; Reese \& Shoemaker, 2016). In their hierarchical influence model, Shoemaker and Reese explained that the micro level refers to individual attitudes and routine practices of journalists, the meso level summarizes factors related to the media organization, and the macro level refers to social institutions and social systems.

Despite many cultural similarities between Indonesia, Malaysia, and Singapore, which are located in the same corner of the region, there are important differences between the countries related to press freedom. Freedom House rated Indonesia's media system as partly free and Singapore's and Malaysia's as not free (see Table 1). A survey of journalists in the three countries as part of the World of Journalism Study also supports this rating (see Table 1). Journalists were asked which factors (out of 27) restrain their work the most. Censorship is ranked in ninth place by Indonesian journalists. Meanwhile, in Malaysia and Singapore, censorship comes in fifth place. The influence of the military, police, state security, and government officials on journalists' work is perceived as more relevant in Malaysia and Singapore than in Indonesia. Based on these findings, it can be expected that Indonesian journalists have more freedom to report problems and to criticize or to blame the responsible actors in the news. Thus, we propose the first hypothesis:

[H1] Media in Indonesia will focus more on problems and moral evaluations than media in Malaysia and Singapore.

Table 1: Structural Condition of Indonesia, Singapore, and Malaysia

\begin{tabular}{|c|c|c|c|}
\hline \multirow{2}{*}{ Structural Condition } & \multicolumn{3}{|c|}{ Countries } \\
\hline & Indonesia & Malaysia & Singapore \\
\hline \multicolumn{4}{|l|}{ Media System } \\
\hline Press freedom status ${ }^{a}$ & partly free & not free & not free \\
\hline \multicolumn{4}{|l|}{ Journalists' perceived influence of ${ }^{b}$} \\
\hline Censorship (rank) & 9 & 5 & 5 \\
\hline Government officials (rank) & 22 & 16 & 13 \\
\hline Military, police, and state security (rank) & 24 & 18 & 8 \\
\hline \multicolumn{4}{|l|}{ Structural Conditions } \\
\hline Size $\left(\mathrm{km}^{2}\right)^{\mathrm{c}}$ & $1,904,569$ & 329,847 & 719,200 \\
\hline Population (millions.) ${ }^{d}$ & 255.2 & 31.2 & 5.3 \\
\hline Population affected by the haze (millions) & 32.5 & 18 & 5.3 \\
\hline Population affected by the haze (\%) & 12.7 & 57.8 & 100 \\
\hline
\end{tabular}

Source: (a). Freedom House, www.freedomhouse.org; (b). Muchtar and Masduki (2016); Hasim, Tiung, Othman, Kee, Waheed, and Nayan (2016); Duffy and Kim (2016). Question in the survey: Here is a list of potential sources of influence. Please tell me how much influence each of the following has on your work. 5 means it is extremely influential, 4 means very influential, 3 means somewhat influential, 2 means less influential, and 1 means not influential. The value shows the rank of the items from rank 1 (most influential) to rank 27 (least influential); (c). The CIA World Fact Book, www.cia.gov/library/publications/the-world-factbook; (d). The Indonesian Central Bureau of Statistics, Department of Statistics Malaysia, and Department of Statistics Singapore; $€$. Sum of the total population in the affected provinces/states in each country (Indonesia: Jambi, South Sumatra, Riau, South Kalimantan, East Kalimantan, Central Kalimantan and West Kalimantan. Malaysia: Sarawak, Johor, Melaka, Negeri Sembilan, Putrajaya, Kuala Lumpur, Selangor, and Pulau Pinang). 
The three countries also differ about specific structural conditions that are relevant to the perception and interpretation of the forest fires and the resulting haze by the media. National structural conditions can be interpreted as relevant factors on the macro level of the hierarchical influence model (Shoemaker \& Reese, 2014). The relevance of these factors was already shown by Rochyadi-Reetz, Arlt, Wolling, and Bräuer (2019), who applied a similar approach in their research on the framing of renewable energy in 11 countries. Their study shows that national structural conditions, such as available energy resources and the existing level of renewable energy installations in the countries, influence how media frame renewable energy.

In the context of this study, relevant conditions include the varying strength and significance of the economic as well as social impacts of the haze in the three countries. The economic consequences of the transboundary haze problem include the loss of income from trade, tourism, and production activities. However, no reliable quantitative data are available concerning the respective economic impacts. Meanwhile, social impacts cannot be denied. Health problems have been triggered by the haze, but many other aspects of social life have also been affected. Millions of people avoided spending time outdoors for several months, thousands of schools were closed, and disruptions to transportation systems and commerce occurred (Antara, 2015; The Jakarta Post, 2015; The Strait Times, 2015). These impacts apply to all the three countries. However, taking into account the affected parts of the respective populations of the countries, it becomes clear that Singapore is especially impacted, as well as some densely populated parts of Malaysia (including the capital), which suffered even more than most Indonesian areas did. The linear distance between Singapore and the southern parts of Malaysia and the location of the forest fires in Sumatra is much less than Java, where the capital of Indonesia is seated.

Map 1 clearly indicates that Java, the most populated island in Indonesia and the centre of political and economic activity, remained almost untouched by the haze. In Indonesia, sparsely populated parts of the country were the main areas afflicted. Even though the World Bank estimated that the economic loss for Indonesia caused by forest fires in 2015 had reached \$16.1 billion (World Bank, 2016), most Indonesians were not directly affected by the haze. But in Singapore, the haze problem affected the entire population of the country. All Singaporeans saw, breathed, and felt the haze directly (see the comparison in Table 1).

Considering these conditions, it is plausible to expect that mass media in Singapore gave more attention to the problem and its solutions and that Indonesian media gave less attention. However, previous research has shown a persistent pattern of conflict avoidance in Singaporean (and Malaysian) mass media on the issue (Lin, 2018; Massey, 2000). The question arises: have the media in Singapore and Malaysia changed their perspective? Based on the assumption that the relative impact will influence the media coverage more than media-related factors (press freedom), we state the following hypothesis:

[H2] The media in Singapore and Malaysia will put more emphasis on the different aspects of the haze problem and on the immediate solutions to overcome the problem than the media in Indonesia. 


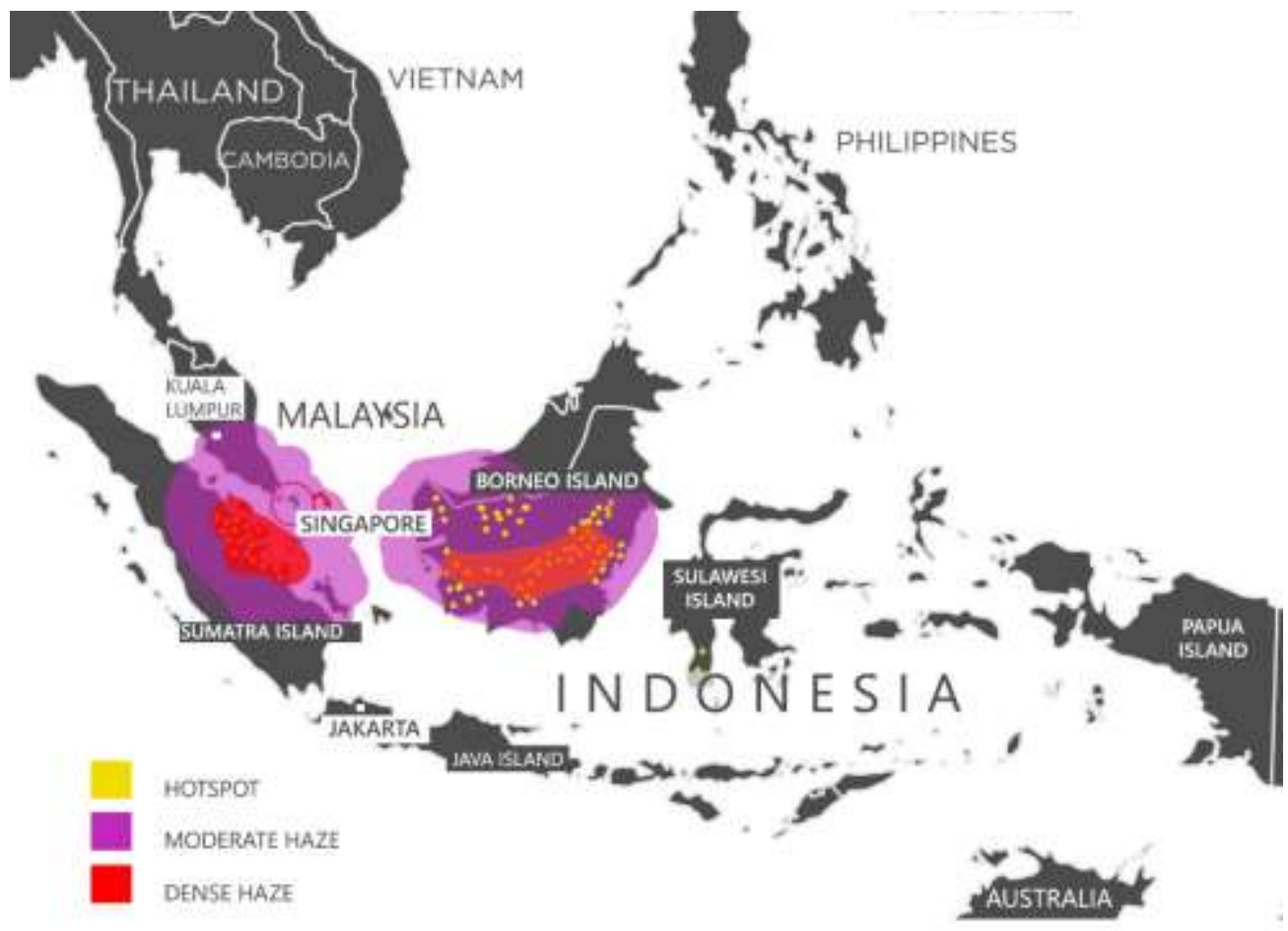

Map 1: Forest Fire Location and Transboundary Haze Area in SEA in 2015

Note: Illustration by authors based on data from the Singaporean National Environmental Agency and the Indonesian Agency for Meteorology, Climatology and Geophysics

\section{METHODOLOGY}

To identify and quantify the relevant frames of the haze problem, this study applies a quantitative content analysis, which is a systematic, replicable, and valid way to measure characteristics of a text by assigning numeric values to specific properties of any symbolic content (Krippendorff, 2013; Riffe, Lacy \& Fico, 1998). To identify the media frames, we applied a manual coding approach. This approach is based on the assumption that "a frame is a certain pattern created by several elements" (Matthes \& Kohring, 2008, p. 264).

This approach uses two steps to identify the frames. In the first step, all frame elements are identified and defined as categories. Afterwards, these categories are used to analyse the coverage by manual content analysis. Relevant content from the articles is assigned to the categories. In the second step, the results of this coding process are analysed using a cluster analysis to identify patterns in the typical structures of the frame elements, which can be interpreted as frames. As a result of this procedure, individual cases of the sample that have specific combinations of frame elements/variables are grouped together. These clusters are interpreted as a collection of articles promoting the same frame on the issue (Matthes \& Kohring, 2008; Entman, Matthes \& Pelicano, 2009). 


\section{Samples}

The unit of analysis in this study consists of articles related to the 2015 SEA problem of haze from online media from Indonesia, Singapore, and Malaysia. The selection of online media outlets (Table 2) was based on the number of subscriptions for their printed versions and the coders' language abilities (English and Bahasa Indonesia). This study chose online media coverage due to its accessibility and the ability to retrieve past articles. The keywords used to identify the articles were "haze" and "haze, Indonesia," and for the media from Indonesia, the keyword used was "kabut asap" (haze). The time frame of the analysis was for articles published between June 2015 (when the problem began) and December 2015 (when the problem ended for the year). Due to the economic and time constraints of the research project, not all available articles could be analysed. A sample of 30 articles from each newspaper was selected (Table 2).

We used the following procedure to draw the sample: during the period of the crisis, we accessed the six websites every week and collected the most relevant articles (based on self-classification of each website). If the most relevant article of a certain media outlet contained at least one frame element, it was included in the sample. If not, the second most relevant was selected (and so on). Thus, articles that only mentioned keywords without further contextualizing the problem in the text were not included in the analysis.

Table 2: Sample description

\begin{tabular}{llll}
\hline \multirow{2}{*}{ Country } & \multicolumn{1}{c}{ Media } & $\begin{array}{c}\text { Number of Articles } \\
\text { Available }\end{array}$ & Sample Size \\
\hline \multirow{2}{*}{ Indonesia } & kompas.com & $>100$ articles & 30 articles \\
& tempo.co.id & $>100$ articles & 30 articles \\
\multirow{2}{*}{ Malaysia } & thestar.com.my & $>100$ articles & 30 articles \\
& nst.com.my & $>100$ articles & 30 articles \\
\multirow{2}{*}{ Singapore } & channelnewsasia.com & $>100$ articles & 30 articles \\
& straittimes.com & $>100$ articles & 30 articles \\
\hline
\end{tabular}

\section{Development of the Codebook}

To capture the data needed to answer the research questions, a codebook was developed as a research instrument. Since the codebook was developed especially for the present study, a pretest needed to be done to check whether the instructions as well as the explanations in the codebook could be easily understood and applied. The coders of this study are two graduate students of media and communication science who are native Indonesian speakers with fluent English ability. They completed their training within two weeks (ten hours of training in each week). Both coders carefully studied the structure and content of the codebook in the first week and applied the coding to ten articles. In the second week, the codebook was pretested. They then identified unclear parts of the codebook and revised some imprecise descriptions of the categories.

The codebook consists of two parts: formal/basic categories and inferential/theoretical categories. The basic categories of the codebook gather key information of the articles, such as the source, the title, the section in which it was published on the website, the publication date, and the length. The inferential/theoretical categories of the codebook were developed by combining the frame elements proposed by Entman (1993) with the dimensions related to the SEA haze problem taken from the previous research by Massey (2000). In the next step, the literature-based codebook was inductively 
complemented. Therefore, 20 articles were randomly selected and used to adjust the codebook. The qualitative analysis of these 20 articles was also used to identify some additional aspects related to the SEA haze problem that had not been mentioned or included in the previous research. Obviously, the haze problem in SEA cannot be separated from forest fires in the region. Therefore, we were keen to include some categories related to the causes of the forest fires.

\section{Intercoder Reliability}

An important quality criteria of a quantitative content analysis is the reliability of measurement. Reliability indicates agreement between coders about the categorization of the content (Riffe, Lacy \& Fico, 1998). Reliability tests are done to ensure the replicability of the findings from the actual content analysis and to encourage researchers to build on the existing codebook for future studies.

To measure the instruments' reliability, two coefficients were calculated. The first was the percentage of agreement by the coders, and the second was Gwet's AC1 coefficient, which was included because it considers the agreement by chance (Gwet, 2008). The results obtained for Gwet's AC1 are more interpretable than the kappa coefficient, which was frequently used in the past (Feinstein \& Chichetti, 1990; Gwet, 2002). The results of the test are depicted in Table 3. Almost all categories show good or very good results. The categories with a somewhat lower coefficient (less than .80, written in bold numbers on Table 3 ) were further improved to increase the clarity of the codebook and thereby the replicability of the results. 
Table 3: Operationalization of Frame Elements and Intercoder Reliability Coefficient $(\mathrm{N}=20)$

\begin{tabular}{|c|c|c|}
\hline Frame Element & $\begin{array}{l}\text { Percentage } \\
\text { Agreement }\end{array}$ & $\begin{array}{l}\text { Gwet's } \\
\text { AC1 }\end{array}$ \\
\hline \multicolumn{3}{|l|}{ Problems Related to Haze } \\
\hline Health problems caused by haze & .80 & .61 \\
\hline $\begin{array}{l}\text { Negative impact on tourism industry (e.g., cancelation of tours } \\
\text { and flights) }\end{array}$ & .95 & .93 \\
\hline Increasing carbon emissions & .90 & .88 \\
\hline High pollution level & .75 & .51 \\
\hline Low visibility range & .95 & .93 \\
\hline Problems in daily activities (e.g., closing of schools) & .80 & .63 \\
\hline Death of animals and ecosystem losses & 1 & 1 \\
\hline Economic losses & .85 & .75 \\
\hline \multicolumn{3}{|l|}{ Factors Causing Haze } \\
\hline Slash-and-burn activities & .70 & .40 \\
\hline Unexpected natural events (e.g., lightning strikes) & 1 & $-^{a}$ \\
\hline Unstable ecosystem from deforestation & .85 & .82 \\
\hline El Niño & 1 & 1 \\
\hline Open burning (e.g., trash and waste burning) & 1 & 1 \\
\hline Weak regulation & 1 & _a \\
\hline Agribusiness by cooperation & .85 & .80 \\
\hline Selection of certain plants in agriculture & .95 & .94 \\
\hline \multicolumn{3}{|l|}{ Moral Evaluation (Who Is Blamed) } \\
\hline Indonesian government & .70 & .66 \\
\hline Government of Singapore & .90 & .89 \\
\hline Government of Malaysia & .90 & .89 \\
\hline ASEAN & 1 & $-^{a}$ \\
\hline NGOs & 1 & 1 \\
\hline Experts & 1 & ${ }^{a}$ \\
\hline Plantation companies & .65 & .80 \\
\hline Farmers & .95 & .95 \\
\hline Local people & .95 & .95 \\
\hline \multicolumn{3}{|l|}{ Solutions to Overcome the Haze Problem } \\
\hline Healthcare treatment (e.g., inhaler, mask, doctor on duty) & .95 & .94 \\
\hline Rain as haze reliever & .95 & .94 \\
\hline $\begin{array}{l}\text { Battling the fires using firemen, military personnel, and } \\
\text { civilians }\end{array}$ & .85 & .73 \\
\hline $\begin{array}{l}\text { Formation of special committee or task force by the } \\
\text { government }\end{array}$ & .75 & .86 \\
\hline Spraying the fire hotspot using airplanes & 1 & ${ }^{a}$ \\
\hline Evacuation of people at risk & .85 & .79 \\
\hline Prosecution of companies violating agriculture regulation & .85 & .82 \\
\hline International assistance and cooperation & .85 & .70 \\
\hline Creating public awareness of forest fires and the haze & .85 & .80 \\
\hline $\begin{array}{l}\text { Policy reform (regulation of the agriculture sector to mitigate } \\
\text { forest fires in the future) }\end{array}$ & .95 & .92 \\
\hline Sustainable agriculture & .95 & .94 \\
\hline $\begin{array}{l}\text { Haze tracking (measurement of density and distribution of the } \\
\text { haze) }\end{array}$ & .75 & .68 \\
\hline Nature conservation & .95 & .95 \\
\hline
\end{tabular}

"Coefficient cannot be calculated since both coders never coded the category "1" 


\section{RESULTS AND DISCUSSION}

The frequencies of the appearance of the different $(A)$ aspects of the problem, (B) causes of the problem, (C) actors held responsible for the problem, and (D) solutions proposed to overcome the problem are depicted in Table 4. The results show that health problems (36.7\%) and the disturbance caused by the haze to people's daily activities $(24.4 \%)$ are the two most mentioned problematic aspects of the haze in 2015. These two problem dimensions were also identified as very prominent in the previous research on the media framing of the 1997 SEA haze problem (Massey, 2000). Meanwhile, the negative impact of forest fires for the climate produced by carbon emissions (5.6\%) and for animals and ecosystem losses (3.9\%) were mentioned in the media least.

When it comes to factors causing forest fires, only a few aspects received attention. The most frequently mentioned factors are slash-and-burn activities to open new plantations (21.7\%), followed by El Niño (15.6\%), and unstable and vulnerable ecosystems due to the long history of deforestation activities in the region (6.1\%). Other causes were widely ignored.

The most frequently mentioned solution to overcome the transboundary haze problem is the immediate extinction of the fires by firefighters, military personnel, and civilians using all available means, such as water bombs, water cannons, and cloud seeds (31.1\%). The second most frequently mentioned solution to the problem is obtaining international assistance and cooperation to overcome the haze problem (26.7\%). A policy reform to mitigate forest fires in the future was also among the most frequently mentioned solutions to the haze problem and came in third place (24.4\%). The argument that the existing regulations are sufficient and merely need to be applied consistently to the companies violating the laws is expressed in $12.7 \%$ of the articles. Furthermore, the media expressed hope that the fires will be extinguished by rainfall (12.8\%). Other remedies focused on alleviating the consequences of the haze, using healthcare (12.2\%) and evacuation (8.3\%).

Even though the seriousness of the problem is widely recognized, and at least every fifth article mentions human activities as the cause, only a very few articles name an actor held responsible for the problem. The plantation companies were mentioned most frequent as culpable ( $9.7 \%$ of the articles), while political actors like the Indonesian government were blamed in less than $2 \%$ of the articles. This reluctance to blame powerful actors might be a culture issue, but it may also be the result of the problematic lack of press freedom, especially in Singapore and Malaysia, but also partly in Indonesia.

To test the first and second hypotheses, we first identified common theoretical dimensions and built indices, combining several frame elements that have similar meanings into new variables (see explanations in the footnote of table 5). Afterwards, the distribution of the new indices for the three countries was compared. Based on the results depicted in Table 5, H1 ("Media in Indonesia will focus more on problems and moral evaluations than media in Malaysia and Singapore") must be rejected. The results show no significant differences between the countries, and in the case of "social problems," the opposite of what was hypothesized appears to be true. In the context of the transboundary haze problem in 2015, journalists in Singapore and Malaysia mentioned social problems in their articles more frequently than journalists from Indonesia. 
Table 4: Frequencies of Frame Elements

\begin{tabular}{|c|c|c|}
\hline \multicolumn{2}{|c|}{ Frame Element } & $\begin{array}{c}\% \\
(\mathrm{~N}=180)\end{array}$ \\
\hline \multicolumn{3}{|c|}{ A. Problems Related to the Haze } \\
\hline 1. & Health problems caused by the haze & 36.7 \\
\hline 2. & Problems in daily activities (e.g., closing of schools) & 24.4 \\
\hline 3. & High pollution level & 22.2 \\
\hline 4. & Low visibility range & 12.2 \\
\hline 5. & Negative impact on tourism (e.g., cancelation of tours and flights) & 10.6 \\
\hline 6. & Economic losses & 8.3 \\
\hline 7. & Increasing carbon emissions & 5.6 \\
\hline 8. & Death of animals and ecosystem losses & 3.9 \\
\hline \multicolumn{3}{|c|}{ B. Factors Causing the Haze } \\
\hline 1. & Slash-and-burn activities & 21.7 \\
\hline 2. & El Niño & 15.6 \\
\hline 3. & Unstable ecosystem from deforestation & 6.1 \\
\hline 4. & Agribusiness by cooperation & 3.3 \\
\hline 5. & Open burning (e.g., trash and waste burning) & 3.3 \\
\hline 6. & Weak regulation & 2.8 \\
\hline 7. & Unexpected natural events (e.g., lightning strikes) & 0 \\
\hline 8. & Selection of certain plants in agriculture & 0 \\
\hline \multicolumn{3}{|c|}{ C. Moral Evaluation (Who Is Blamed) } \\
\hline 1. & Plantation companies & 9.7 \\
\hline 2. & Indonesian government & 1.7 \\
\hline 3. & Farmers & 1.1 \\
\hline 4. & Government of Singapore & 0.6 \\
\hline 5. & Government of Malaysia & 0.6 \\
\hline 6. & Local people & 0.6 \\
\hline 7. & ASEAN & 0 \\
\hline 8. & NGOs & 0 \\
\hline 9. & Experts & 0 \\
\hline \multicolumn{3}{|c|}{ D. Solutions to Overcome the Haze Problem } \\
\hline 1. & Battling the fires by firefighters, military personnel, and civilians & 31.1 \\
\hline 2. & International assistance and cooperation & 26.7 \\
\hline 3. & $\begin{array}{l}\text { Policy reform (regulation of the agriculture sector to mitigate forest } \\
\text { fires in the future) }\end{array}$ & 24.4 \\
\hline 4. & Rain as haze reliever & 12.8 \\
\hline 5. & Healthcare treatment (e.g., inhaler, mask, doctor on duty) & 12.2 \\
\hline 6. & Prosecution of companies that violate agricultural regulations & 11.7 \\
\hline 7. & Evacuation of people at risk & 8.3 \\
\hline 8. & Nature conservation & 3.9 \\
\hline 9. & Creating public awareness of forest fires and the haze & 3.9 \\
\hline 10. & Formation of special committee or task force by the government & 2.2 \\
\hline 11. & Sustainable agriculture & 1.7 \\
\hline 12. & Haze tracking (measurement of density and distribution of haze) & 1.1 \\
\hline 13. & Spraying the fire hotspot using airplanes & 0 \\
\hline
\end{tabular}

Note. Scale: $1=$ mentioned, $0=$ not mentioned. Frame elements with a frequency of less than $5 \%$ were excluded from further analysis since those with low frequencies would not contribute notably to the formation of the cluster analysis (Matthes \& Kohring, 2008). In the case of "moral evaluations," a sum index of all mentioned actors was built.

Accordingly, the data are more in line with $\mathrm{H} 2$ ("Media in Singapore and Malaysia will put more emphasis on the different aspects of the haze problem and on the immediate solutions to overcome the problem than the media in Indonesia"). Due to the severe impact of the haze, which is experienced by all parts of the Singaporean population, Singaporean 
journalists highlighted social problems most, followed closely by Malaysian journalists, while Indonesian journalists mentioned this aspect least often. Furthermore, the Singaporean journalists focused significantly more on recommendations to act immediately. This also supports $\mathrm{H} 2$ at least partly. Finally, it must be mentioned that this difference is not limited to short-term reactions. Long-term solutions are given more salience by the media from Singapore and Malaysia (Table 5).

Table 5: Comparison of Dimensions Between Countries

\begin{tabular}{|c|c|c|c|c|}
\hline \multirow[b]{2}{*}{ Dimensions of Frame Elements ${ }^{a}$} & \multicolumn{3}{|c|}{ Mentioned Dimension per Country (\%) } & \multirow{2}{*}{$\begin{array}{l}\text { Significance } \\
\text { of } \mathrm{Chi}^{2} \\
p\end{array}$} \\
\hline & $\begin{array}{l}\text { Indonesia } \\
(\mathrm{N}=60)\end{array}$ & $\begin{array}{c}\text { Malaysia } \\
(\mathrm{N}=60)\end{array}$ & $\begin{array}{l}\text { Singapore } \\
(N=60)\end{array}$ & \\
\hline Social problems $(\mathrm{A} 1, \mathrm{~A} 2)$ & 36.7 & 48.3 & 53.3 & $<.05$ \\
\hline Air pollution problems $(A 3, A 7)$ & 15.0 & 36.7 & 26.7 & n.s. \\
\hline Economic problems $(\mathrm{A} 4, \mathrm{~A} 5, \mathrm{~A} 6)$ & 28.3 & 30.0 & 30.0 & n.s. \\
\hline Factors causing forest fires $(\mathrm{B} 1, \mathrm{~B} 2, \mathrm{~B} 3)$ & 6.7 & 8.3 & 16.7 & n.s. \\
\hline $\begin{array}{l}\text { Recommendations for immediate } \\
\text { reaction (D1, D4, D5, D7) }\end{array}$ & 35.0 & 22.0 & 58.3 & $<.05$ \\
\hline $\begin{array}{l}\text { Recommendations for long-term action } \\
(D 2, D 3, D 6)\end{array}$ & 26.7 & 46.7 & 55.0 & $<.01$ \\
\hline $\begin{array}{l}\text { Moral evaluation }(\mathrm{C} 1, \mathrm{C} 2, \mathrm{C} 3, \mathrm{C} 4, \mathrm{C} 5 \text {, } \\
\mathrm{C6})\end{array}$ & 6.7 & 8.3 & 16.0 & n.s. \\
\hline \multicolumn{5}{|c|}{$\begin{array}{l}\text { a The denominations in brackets (e.g., A1, A2, B1, B2 . .) refer to the categories in Table } 4 \text {. For example } \\
\text { the social problems category above was built as a sum index of } \mathrm{A} 1 \text { (health problems caused by the haze) } \\
\text { and } \mathrm{A} 2 \text { (problems in daily activities [e.g., closing of schools]). The numbers in the table indicate the } \\
\text { percentage of articles in which the respective category appeared at least once. }\end{array}$} \\
\hline
\end{tabular}

To identify patterns of frame elements in the coverage on the transboundary haze crisis in 2015, we applied a cluster analysis to all seven dimensions depicted in Table 5 using the statistic software R. By means of the cluster analysis (Table 6), we identified three frames. These frames indicate different perspectives on the haze issue. The first cluster consists of only 17 articles (9.4\%). Articles in this cluster frame the issue as a salient problem. All problematic aspects of the issue are covered, and the causes of the problem are also pointed out. Furthermore, the authors of the articles highlighted the need for response: both shortterm and long-term solutions to the problem are mentioned. Based on these characteristics, this cluster is called "crisis frame."

Table 6: Clusters of Media Frames ( $\mathrm{N}=180)$

\begin{tabular}{|c|c|c|c|c|c|}
\hline \multirow[b]{2}{*}{ Frame Element } & \multicolumn{3}{|c|}{ Mean Value $^{\text {b }}$} & \multirow[b]{2}{*}{ F-Score } & \multirow[b]{2}{*}{$p$} \\
\hline & $\begin{array}{l}\text { Crisis } \\
\text { Frame }\end{array}$ & $\begin{array}{c}\text { Immediate } \\
\text { Action Frame }\end{array}$ & $\begin{array}{c}\text { Regular } \\
\text { Problem Frame }\end{array}$ & & \\
\hline $\begin{array}{c}\mathrm{n} \\
\text { (\% of sample) }\end{array}$ & $\begin{array}{c}17 \\
(9.4)\end{array}$ & $44(24.4)$ & $119(66.1)$ & & \\
\hline Social problem (scale: 0-2) & 1.59 & 0.50 & 0.51 & 20.1 & $<.001$ \\
\hline Air quality problem (scale: $0-2$ ) & 0.94 & 0.09 & 0.25 & 23.1 & $<.001$ \\
\hline Economic problem (scale: 0-2) & 1.29 & 0.20 & 0.36 & 19.2 & $<.001$ \\
\hline Cause of haze (scale: $0-3$ ) & 1.94 & 0.09 & 0.34 & 73.4 & $<.001$ \\
\hline $\begin{array}{l}\text { Immediate action to overcome } \\
\text { haze (scale: } 0-4 \text { ) }\end{array}$ & 1.00 & 1.70 & 0.20 & 117 & $<.001$ \\
\hline $\begin{array}{l}\text { Long-term action to overcome } \\
\text { haze (scale: } 0-2 \text { ) }\end{array}$ & 0.88 & 0.59 & 0.45 & 2.6 & n.s. \\
\hline Moral evaluation (scale: $0-2$ ) & 0.12 & 0.04 & 0.15 & 1.5 & n.s \\
\hline
\end{tabular}

Note: This table presents a hierarchical cluster analysis with ward method and Euclidean distance. 
The second frame, which appears in $23.3 \%$ of all articles, is called the "immediate action frame," since the main focus of the articles in this cluster is on the need to take immediate action to overcome the problem by fighting the causes and the effects of the haze. This frame consists of articles that address, for example, the battle against the fire, the distribution of anti haze masks, or the evacuation of people from the haze area. Articles in this cluster widely ignore other aspects and views on the problem. Neither the different problematic aspects nor the underlying causes receive considerable attention.

By far the largest cluster is the last one. Nearly two out of every three articles belong to this cluster. The common characteristic of these articles is that they do not have a clear focus. Some mention single problems, while others mention causes or treatment recommendations, but a specific combination of frame elements cannot be identified. The mean values of all of the frame elements are quite low. The highest one belongs to human health problems, but even this aspect only appears in every second article of this cluster. Accordingly, this cluster portrayed the issue as less than a crisis and did not even emphasize the importance of combating the problem immediately or structurally. Articles in the third cluster treat the haze issue as a casual problem that occurs regularly almost every year. Therefore, it is not worthwhile to make a fuss about it. Thus, we named the third cluster the "regular problem frame."

\section{Media Framing of the Haze Issue in Indonesia, Singapore, and Malaysia}

As a last step, a cross-tabulation analysis was conducted to determine whether there are differences in the media framing of the SEA haze issue between Indonesia, Singapore, and Malaysia. The results show that the media in Singapore and Malaysia applied the crisis frame more often than the Indonesian media (Table 6). In comparison to the other two countries, the media in Singapore reported more about the immediate response against the fires and the haze (31.7\% of all articles): more than Indonesian journalists (26.7\%) and Malaysian reporters $(15.0 \%)$. The last frame prevailed in all three countries but with different explicitness. For the Malaysian media (75.0\%) as well as for the Indonesian media (71.7\%), the regular problem frame was clearly the dominant one, while in Singapore this frame was applied in a much lower frequency (51.6\%).

Table 7: Media Frames of the Haze Issue in Indonesia, Singapore, and Malaysia

\begin{tabular}{lccc}
\hline & Indonesia & Malaysia & Singapore \\
\hline $\mathrm{N}$ & 60 & 60 & 60 \\
Crisis frame & $1.6 \%$ & $10.0 \%$ & $16.7 \%$ \\
Immediate action frame & $26.7 \%$ & $15.0 \%$ & $31.7 \%$ \\
Regular problem frame & $71.7 \%$ & $75.0 \%$ & $51.6 \%$ \\
\hline
\end{tabular}

Note. $\mathrm{Chi}^{2}=12.057, \mathrm{p}<.01$ 
The differences in framing in Indonesia, Singapore, and Malaysia could be explained by the varying impact of the haze problem on the population of the three countries. The haze caused by forest fires in Indonesia affected everyone in Singapore. The ongoing air pollution caused by the haze has made life in the densely populated city of Singapore (about 8,000 persons $/ \mathrm{m}^{2}$ ) onerous. This factual condition has influenced the coverage of the Singaporean mass media, which usually avoids crisis frames and the blaming of responsible actors in their coverage.

Meanwhile, the absence of the crisis frame in Indonesia and the dominance of the regular problem frame might be caused by the distance from the haze-choked areas, which are Borneo and Sumatera, both far away from Jakarta or Java. Since the media landscape in Indonesia is highly centralised in Java and Jakarta (Armando, 2014; Lim, 2012; Rochyadi-Reetz \& Löffelholz, 2019), much emphasis is not put on other parts of the country including the national government and most citizens of Indonesia, who are highly concentrated in Java, do not suffer directly from the haze. This might create a certain distance from the crisis in Indonesia in comparison to Singapore and Malaysia, which are geographically closer to the location of the forest fires and more directly affected by the haze.

Despite the high percentage of crisis framing in Singapore and Malaysia, media from both countries also show a high proportion of regular problem framing in their coverage. Looking at the position of those countries as victims of the haze crisis, this result appears to be somewhat surprising. However, keeping in mind that many palm oil companies in Indonesia, which are regarded as the most responsible actors for causing forest fires, are owned by Malaysian and Singaporean companies (WWF \& Enviro Market, 2012), this might explain why the media in Singapore and Malaysia almost never blame the Indonesian government. When it comes to palm oil, all three countries share similar economic interests.

\section{CONCLUSION}

Given the strong social, economic, and environmental impacts of the periodical transboundary SEA haze problem, media and communication research into these catastrophes has been surprisingly limited. Only two studies, conducted within a two-decade period, were identified (Lin, 2018; Massey, 2000). Both studies show similar patterns of media framing. Building on these findings, we identified some additional dimensions that did not appear in the earlier studies. To identify the underlying frames, we applied a cluster analysis to the coded dimensions instead of using predefined holistic frames. It can be argued that such an inductive approach is problematic if the aim of a study is hypothesis testing, as in our case, and that "generic frames are more suited" (Matthes 2009, p. 356). However, our research demonstrates that hypothesis testing is also doable based on inductive issue-specific frames.

In our research we identified three frames in the media coverage of the 2015 SEA haze issue: the crisis frame, the immediate action frame, and the regular problem frame. The dominant frame in all three countries was the regular problem frame, which treats the SEA haze issue as a common, unspectacular incident and contains few detailed explanations of the problem and its causes and almost no critical content at all. This result is comparable with the findings from Massey (2000) and Lin (2018). Thus, this downplaying of the disaster seems to be a stable form of issue-specific framing on the transboundary haze problem in the SEA region. However, the proportion of the three frames differs between the countries. 
To explain the differences in the coverage, this study proposes two explanations: the varying degree of press freedom and the influence of structural conditions. Within the context of this research, structural conditions refer to the significance of the impact of the haze on the societies in the three countries.

The limited press freedom in all the three countries could be an explanation for the overall low number of articles framing the haze problem as a "crisis" and the dominance of the regular problem frame. However, the fact that the Indonesian media are somewhat more free cannot explain the differences in the coverage. On the contrary, it was observed that the Indonesian media are even less critical than their counterparts from Malaysia and Singapore. This phenomenon of uncritical media coverage on the transboundary haze issue could be explained better by the structural conditions that influenced how the haze impacted the countries. Media from Singapore, a small country in which the whole population was highly impaired by the haze, applied the crisis frame most often followed by Malaysia, while the Indonesian media almost never covered the issue as a crisis. This finding supports the applicability of the concept of structural conditions proposed by Rochyadi-Reetz et al. (2019), which is rooted in the hierarchical influence model introduced by Shoemaker and Reese (2014). Accordingly, our study and analyses contribute to the theoretical discussion on the influences of the formation of issue-specific frames.

This study adds some valuable knowledge to the understanding of comparative media research in general and especially to the research on media's framing of environmental disasters. Furthermore, it provides important insights into how this specific crisis was covered by the media. However, some limitations must also be considered. The first limitation relates to the sample of newspapers. Due to limited access and resources, the sample was drawn from only two online media from each country. Future research should include larger samples and the print versions of the newspapers as well as, ideally, TV in the analysis. In addition, it should compare forest fire/haze coverage between national newspapers in Indonesia, where they are published in Jakarta, and local newspapers, which are located in areas with high density of haze. This study was also restricted to text and did not analyse the visual frames of the haze crisis. Without a doubt, visual media communication is a powerful tool for arousing readers' emotions and involvement in a crisis (Normah \& Faridah, 2018).

To understand the evolution of public discourse on the haze crisis in the region, future research should compare the media coverage of the transboundary haze crisis in 2015 with the latest disaster in 2019, which once again engulfed several countries in the SEA region. One example of a long-term analysis of media coverage is the study conducted by Yell (2010) on the bushfires in Australia. Since the SEA countries perceived the haze problem as a crisis for the entire region, it would be valuable to apply a crisis communication approach to analyse the media discourse on the issue. While our research focused on the hot period (crisis stage), it did not consider the early and the late stages of the incident. Therefore, we propose that future research should also analyse how the media frame the issue before the annual burning season starts (pre-crisis stage) and after the disaster, when the fires are extinguished and the haze has moved on (post-crisis stage). This approach was applied in the work of Warsihantari and Putra (2018) and Lin (2018).

Last but not least, as the occurrence of forest fires is closely related with climate change, an investigation into how far both issues are presented as interconnected is highly relevant. Do the media consider the consequences of the forest fires for the climate, and is climate change discussed as a reinforcing factor of the recurrent disasters? 


\section{ACKNOWLEDGEMENT}

The authors acknowledge the financial support for the Article Processing Charge by the German Research Foundation (DFG) and the Open Access Publication Fund of the Technische Universität Ilmenau.

\section{BIODATA}

Mira Rochyadi-Reetz is a junior research assistant of the department of Empirical Media Research and Political Communication Technische Universität Ilmenau, Germany Email: mira.rochyadi-reetz@tu-ilmenau.de

Olivia Deskarina Budiono is Media Manager at the German Academic Exchange Service Jakarta. She received her MA from the Technische Universität IImenau-Germany. Email: oliviadeskarina@gmail.com

Jens Wolling is a professor in department of Empirical Research and Political Communication, Technische Universität IImenau, Germany. Email: jens.wolling@tuilmenau.de 


\section{REFERENCES}

$A B C$. (2015, Oct 03). Indonesian fires sending haze across Southeast Asia could become worst on record, NASA warns. Retrieved from https://www.abc.net.au/news/2015-1002/indonesia-forest-fires-could-become-worst-on-record-nasa-warns/6824460

Antara. (2015, Sept. 11). More Indonesia airports affected by haze from land fires. Retrieved from https://en.antaranews.com/news/100446/more-indonesia-airports-affectedby-haze-from-land-fires

Armando, A. (2014). The greedy giants: Centralized television in post-authoritarian Indonesia. International Communication Gazette, 76(4-5), 390-406.

Carvalho, A., \& Burgess, J. (2005). Cultural circuits of climate change in U.K. broadsheet newspapers, 1985-2003. Risk Analysis, 25(6), 1457-1469. https://doi.org/10.1111/j.1539-6924.2005.00692.x

Duffy, A., \& Kim, W. (2016). Country report: Journalists in Singapore. World of Journalism Study. Retrieved from https://epub.ub.unimuenchen.de/32016/1/Andrew_Duffy_Wee_Kim_Journalists_in_Singapore.pdf

Entman, R. M. (1993). Framing: Towards clarification of a fractured paradigm. Journal of Communication, 43(4), 51-58.

Entman, R. M., Matthes, J., \& Pellicano, L. (2009). Nature, sources, and effects of news framing. In K. Wahl-Jorgensen \& T. Hanitzsch (Eds.), The handbook of journalism studies (pp. 175-190). New York: Routledge.

Feinstein, A. R., \& Cicchetti, D.V. (1990). High agreement but low kappa: The problems of two paradoxes. Journal of Clinical Epidemiology, 43(6), 543-549. https://doi.org/10.1016/0895-4356(90)90158-I

Gwet, K. L. (2002). Kappa statistic is not satisfactory for assessing the extent of agreement between raters. Statistical Methods for Inter-Rater Reliability Assessment, No. 1. Retrieved from http://agreestat.com/papers/papers/kappa_statistic_is_not_satisfactory.pdf

Gwet, K. L. (2008). Computing inter-rater reliability and its variance in the presence of high agreement. The British Journal of Mathematical and Statistical Psychology, 61(Pt 1), 29-48. https://doi.org/10.1348/000711006X126600

Hasim, M. S., Tiung, L. K., Othman, S. S., Kee, C. P., Waheed, M., \& Nayan, L. M. (2016). Country report: Journalists in Malaysia. World of Journalism Study. Retrieved from https://epub.ub.uni-muenchen.de/29709/1/Country_report_Malaysia.pdf

Jones, D. S. (2004). ASEAN initiatives to combat haze pollution: An assessment of regional cooperation in public policy-making. Asian Journal of Political Science, 12(2), 59-77. https://doi.org/10.1080/02185370408434242

Krippendorff, K. (2013) Content analysis. An introduction to its methodology (3rd ed.). California, CA: Sage Publications.

Lin, T. T. C. (2018). Communicating haze crisis online: Comparing traditional media news and new media perspectives in Singapore. Environmental Communication, 13(7), 864-878.

Lim, M. (2012). The league of thirteen: Media concentration in Indonesia. Tempe, Arizona: Participatory Media Lab at Arizona State University and The Ford Foundation. Retrieved from http://www.public.asu.edu/ mlim4/files/Lim_IndoMediaOwnership_2012.pdf

Massey, B. L. (2000). How three Southeast-Asian newspapers framed the haze of 1997-98. Asian Journal of Communication, 10(1), 72-94. https://doi.org/10.1080/01292980009364776 
Matthes, J. (2009). What's in a frame? A content analysis of media framing studies in the world's leading communication journals, 1990-2005. Journalism \& Mass Communication Quarterly, 86(2), 349-367. https://doi.org/10.1177/107769900908600206

Matthes, J., \& Kohring, M. (2008). The content analysis of media frames: Toward improving reliability and validity. Journal of Communication, 58(2), 258-279. https://doi.org/10.1111/j.1460-2466.2008.00384.x

Monbiot, G. (2015). Indonesia is burning. So why is the world looking away? Retrieved from http://www.theguardian.com/commentisfree/2015/oct/30/indonesia-fires-disaster21st-century-world-media

Muchtar, N., \& Masduki. (2016). Country report: Journalists in Indonesia. Worlds of Journalism Study. Retrieved from https://epub.ub.unimuenchen.de/30120/1/Country_report_Indonesia.pdf

Normah Mustaffa, \& Faridah Ibrahim. (2018). Pembingkaian visual berita krisis Lahad Datu. Jurnal Komunikasi: Malaysian Journal of Communication, 34(1), 170-184. https://doi.org/10.17576/JKMJC-2018-3401-10

Pan, Z., \& Kosicki, G. M. (1993). Framing analysis: An approach to news discourse. Political Communication, 10, 55-75.

Reese, S. D., \& Shoemaker, P. J. (2016). A media sociology for the networked public sphere. The hierarchy of influences model. Mass Communication and Society, 19(4), 389-410. https://doi.org/10.1080/15205436.2016.1174268

Riffe, D., Lacy, S., \& Fico, F. (1998). Analyzing media messages: Using quantitative content analysis in research. Mahwah, NJ: Erlbaum.

Rochyadi-Reetz, M., Arlt, D., Wolling J., \& Braeuer, M. (2019). Explaining the media's framing of renewable energies: An international comparison. Front. Environ. Sci,. 7, 119. https://doi.org/10.3389/fenvs.2019.00119

Rochyadi-Reetz, M., \& Löffelholz, M. (2019). A pressing tale of two countries: Comparing the media systems of Indonesia and Germany. In Grüne, A., Kai Hafez, K., Priyadharma, S., \& Schmidt, S. (Eds.), Media and transformation in Germany and Indonesia: Asymmetrical comparisons and perspectives. Berlin: Frank \& Timme.

Shoemaker, P. J., \& Reese, S. D. (2014), Mediating the message in the 21st century: A media sociology perspective (3rd ed.). London: Routledge; Taylor \& Francis Group.

The Jakarta Post. (2015, August 3). Islands in focus: City to extend school closure over haze frenzy. Retrieved from https://www.thejakartapost.com/news/2015/08/03/islandsfocus-city-extend-school-closure-over-haze-frenzy.html

The Straits Times. (2015, October 6). Schools closed in Malaysia as haze reaches hazardous levels. Retrieved from https://www.straitstimes.com/asia/se-asia/schools-closed-inmalaysia-as-haze-reaches-hazardous-levels

Varkkey, H. (2016). The haze problem in Southeast Asia: Palm oil and patronage. New York: Routledge.

Warsihantari, N. K. D., \& Putra, I. G. N. (2018). Air Asia crisis communications strategies and Malaysia Airlines: A content analysis. Jurnal Komunikasi Ikatan Sarjana Komunikasi Indonesia, 3(1). https://doi.org/10.25008/jkiski.v3i1.145

Worldbank. (2016). The cost of fire: An economic analysis of Indonesia's 2015 fire crisis. Retrieved from http://pubdocs.worldbank.org/en/643781465442350600/Indonesiaforest-fire-notes.pdf 
WWF \& Enviro Market. (2012). Palm oil investor review 2012. Retrieved from http://www.rspo.org/file/Palm\%200il\%20Investor\%20Review\%20Web\%20Version.p df

Yell, S. (2010). Breakfast is now tea, toast and tissues: Affect and the media coverage of bushfires. Media International Australia, 137(1), 109-119. 